\title{
12. Invoking the Holy Trilogy
}

\author{
Star Wars in the Askewniverse
}

Andrew M. Butler

In Kevin Smith's Clerks. (The Comic Book) (1998), Randal Graves observes to his lifelong friend Dante Hicks that "Star Wars is probably the biggest thing that ever did or ever will happen to our generation." Smith asserts that his age group had "a childhood affair with three movies that were the cinematic equivalent of a prepubescent first marriage. ${ }^{2}$ Star Wars fed into Smith's personal values, identity, and creative output: "a de rigueur Star Wars conversational dissection or homage became one of the leitmotifs of View Askew's body of work." ${ }^{\prime 3}$ The first dozen years of Smith's directorial output are dominated by six interconnected films-Clerks (1994), Mallrats (1995), Chasing Amy (1997), Dogma (1997), Jay and Silent Bob Strike Back (2001), and Clerks II (2006) - that constitute the transmedia franchise of the View Askewniverse or Askewniverse, after Smith's production company. In addition, the franchise includes Clerks: The Animated Series (2000) and a number of comic books, in particular Clerks. (The Comic Book). The many references to Star Wars act both as a means of defining Askewniverse characters' self-identities through their consumption of popular culture and as a form of advertising - unpaid labor for Lucasfilm. I will examine the nature of this labor within the Askewniverse as it depicts twenty-somethings in a variety of ways earning a living within late capitalism.

In Marxian terms, identity is derived from the individual's relation to the economic base of a society, including the manner of labor exchange for wages. But labor can take a number of different forms-productive, intellectual, spectatorial, and so on. Laborers sell labor to produce articles with use-value that may be exploited by capitalists to produce capital derived from exchange-value. In Marx's own words, capitalists "appropriate the produce of the labour of others by alienating [entfremden] the produce of

1 Clerks. (The Comic Book), written by Kevin Smith, drawn by Jim Mafhood, and lettered by Sean Konot (Portland, OR: Oni Press, 1998), 12.

2 Kevin Smith, "Married to the Force," in A Galaxy Not So Far Away: Writers and Artists on Twenty-Five Years of Star Wars, ed. Glenn Kenny (New York: Henry Holt, 2002), 72.

3 Smith, "Married," 72. View Askew Productions is the name of Kevin Smith's production company, which produced the Askewniverse films. His other feature films, television, podcasts, and comic work are beyond the scope of this chapter. 
their own." For example, a father might labor to provide shelter, food, and clothing for his family, as well as consumer goods and entertainment, some of which contribute to an ideological state that Marx describes as false consciousness. Wages provide the laborer with the possibility to consume something like Star Wars, but, at the same time, this particular act of consumption turns them into "laborer-watchers."

For the worker, a day only partly consists of sleeping and working, with the rest of it used in a number of different ways, including eating, consumption, and leisure. Dallas Smythe argues that "[o]f the off-the-job work time, the largest single block is time of the audiences which is sold to advertisers." 5 The audience consumes media such as films, sitcoms, or sports coverage, but this also subjects them to advertisements. Audiences as laborer-watchers are sold to advertisers of branded goods. In watching a Star Wars movie, the audience views commercials and trailers, and is interpolated into a transmedia franchise of sequels, prequels, and merchandising.

Building on Smythe's work, Sut Jhally and Bill Levant argue that the history of twentieth-century television is one of an increasing blur between programs and commercials, "converting program into ad [...] converting consumption watching-time into labor watching-time." ${ }^{16}$ While the Star Wars films themselves would normally not include advertisements, the merchandising of characters and vehicles effectively transforms the films into ads, just as the toys become commercials for the films. The laborerwatcher is alienated and commodified, even as play creates forms of cultural or social capital. M.J. Clarke argues that "the more we live in branded worlds, the more we must learn how people can express themselves in and through brands."7 As Clerks.'s comic-book version of Randal asserts, "if there's an angle by which we can profit from 'the Force' in our little corner of the world, then why don't we?" 8 Randal is aware of the capitalism underlying the Star Wars franchise and the way in which he has been constructed as consumer and laborer-watcher. By intervening in the sale of merchandising, Randal hopes to enrich himself economically and perhaps increase his agency, especially if it comes with the social capital attached to rare toys.

4 Karl Marx, Capital Volume One, trans. Ben Fowkes (London: Pelican, 1976), 203.

5 Dallas Smythe, "Communications: Blindspot of Western Marxism," Canadian Journal of Political and Social Theory 1, no. 3 (1977): 2.

6 Sut Jhally and Bill Levant, "Watching as Working: The Valorization of Audience Consciousness," Journal of Communication 36, no. 3 (1986): 141.

7 M.J. Clarke, "Branded Worlds and Contracting Galaxies: The Case of Star Wars Galaxies," Games and Culture 9, no. 3 (2014): 205.

8 Clerks. (The Comic Book), 12. 
Another unifying factor in the Askewniverse is the presence of two drug dealers: the sex-obsessed and foul-mouthed Jay and the appropriately named Silent Bob. On at least two occasions, Silent Bob quotes Yoda from The Empire Strikes Back- "Adventure. Excitement. A Jedi craves not these things" (Mallrats) and "Do. Or do not. There is no try" (Chasing Amy)—as well as trying to use the Force to levitate a cigarette and then a videocassette at various points in Mallrats. In Dogma, the only Star Wars reference comes when Bethany recruits them to her mission and Jay observes to Bob: "I feel like I'm Han Solo, and you're Chewie, and she's Ben Kenobi, and we're in that fucked up bar." As ancillary characters, Jay and Silent Bob perform a kind of Greek chorus throughout the films, while also offering parallels to the uninhibited Randal and repressed Dante (Clerks, Comic Book, Animated Series, Clerks II), Brodie Bruce and T.S. Quint (Mallrats), and Banky Edwards and Holden McNeill (Chasing Amy, Jay and Silent Bob Strike Back). Smith recalls a French critic at Cannes asking if "The foul-mouth an' ze fat man outside ze shop [...] are zey the Artoo De-too an' See-Threepio of zis strange universe you 'ave created?'”

Alongside their appropriation of the street as a market space, Jay and Silent Bob are also laborer-watchers. The Star Wars media franchise that they labor through was itself the product of a failure to gain the rights to an intellectual property: George Lucas had wanted to adapt Flash Gordon. Instead, he laminated Joseph Campbell's monomyth onto space opera, while drawing upon other genres such as Saturday chapter serials, the Western, and the war movie, as well as specific influential texts, including The Hidden Fortress (1958), The Wizard of $\mathrm{Oz}$ (1939), and The Lord of the Rings (1949-1950). In the decade after 2001: A Space Odyssey (1968), much science-fiction film had been dystopian rather than escapist; for example, Lucas's own THX-1138 (1971), Soylent Green (1973), and Zardoz (1974). A New Hope offered a more optimistic spectacle during a period of American stagflation and disillusionment. Luke Skywalker was an unambiguous hero in an antiheroic era, recuperating the American Dream after the Bicentennial, while rewriting military history; whatever Lucas's personal politics, the trilogy anticipated the neoconservatism of Ronald Reagan, which reached its zenith in the Strategic Defense Initiative (colloquially known as Star Wars).

Robin Wood labels the trilogy's ideology Reaganite, arguing that it reassures audiences about the dangers of fascism and the atom bomb by

9 Smith, "Married," 71. It might be problematic pushing the parallel too far- $-\mathrm{C}-3 \mathrm{PO}$ is sensible but far from silent. 
saying "don't worry, Uncle George [...] will take you by the hand and lead you through Wonderland [...] never fear, he'll also see you safely home."10 The audience willingly becomes childlike again, lulled by the Wonderland of special effects. The patriarch is reinstated as authoritative figure whose role must be inherited by the son; Luke must follow the example of the "good father" Obi-Wan and repudiate the attitudes of the "bad father" Darth Vader. Then, once Vader is revealed to be Luke's biological father Anakin, the narrative arc of the holy trilogy becomes the redemption of the father; the prequel trilogy thus constitutes the narrative of the good father's temporary fall.

As I have already noted, parents usually support their children economically, with pre-teen viewers the perfect age to watch the Star Wars films. Whether merchandising is a present or bought with pocket money, it is a gift from parents, as Smith's first Star Wars toys were. Smith had seen the Kenner Star Wars Early Bird set toys even before his first viewing of $A$ New Hope at around age seven. ${ }^{11} \mathrm{He}$ financed the semi-autobiographical Clerks, set in a convenience store and the neighboring video rental store, by selling his comics collection, maxing out credit cards, and repurposing his college fund. But while his characters constantly reference Star Wars and other popular texts, Smith's debut is aesthetically closer to films by Spike Lee, Jim Jarmusch, and Richard Linklater than to the blockbusters his characters obsess over. Smith's oeuvre is characterized by meandering, talky vignettes, echoing the more non-linear career path Generation Xers experienced in contrast to their Baby Boomer parents' linear career trajectories.

In a 1990 Time magazine article, David M. Gross and Sophfronia Scott noted that Generation Xers "have trouble making decisions. They would rather hike in the Himalayas than climb a corporate ladder. [...] They crave entertainment, but their attention span is as short as one zap of a TV dial. [...] They postpone marriage because they dread divorce." The restricted geography of Clerks echoes this sense of entrappedness-in dead-end McJobs, ambivalent about college, stuck living with parents-and offers a late-capitalist equivalent to Luke at the start of $A$ New Hope. Dante is alienated, stuck selling groceries. The immaterial labor of clerks such as Dante is located within the shop, a location for "the realisation of profit, [...] the designed stage for marketing commodities, as the form that aggregates

10 Robin Wood, Hollywood from Vietnam to Reagan (New York: Columbia University Press, 1987), 165-166.

11 A New Hope was released May 25, 1977. Smith's memory of seeing the Kenner Star Wars Early Bird Set is in June 1977 (Smith, "Married," 73). 
specific products, coordinates logistics and distribution, and that organises access to commodities within the built environment.".12 This increasingly invisible form of labor is productive of surplus value, but not of material objects.

Dante and Randal attempt to make life bearable via their shared cultural knowledge of Star Wars, for example, having conversations about which is the better film:Return of the Jedi or The Empire Strikes Back. As Dante claims,

Empire had the better ending: Luke gets his hand cut off, and finds out Vader's his father; Han gets frozen and taken away by Boba Fett. It ends on such a down note. And that's life—a series of down endings. All Jedi had was a bunch of Muppets.

The two friends also have an ethical discussion about what happened to the workers on the Death Star. ${ }^{13}$ Personnel in the one destroyed by Luke in A New Hope were part of the Empire and thus culpable, Dante argues, but the one destroyed by Lando Calrissian in Return of the Jedi would have been occupied by construction workers. Randal is bothered by "All those innocent contractors hired to do a job [who] were killed—casualties of a war they had nothing to do with." A construction worker who overhears their debate at the Quick Stop interrupts to correct them, recalling a job for a gangster that he had turned down: "You know, any contractor willing to work on that Death Star knew the risks. If they were killed, it was their own fault. A roofer listens to this ... [taps his heart] not his wallet." The Death Star thereby becomes "a way of imagining the totality that surrounds them, ${ }^{114}$ which is to say the capitalist system. Whilst the worker has little choice but to labor, there is clearly an ethics of where and for whom to labor.

The Death Star is also referenced in Mallrats, Smith's second feature in which the two central characters, T.S. Quint and Brodie Bruce, are trying to reunite with their respective ex-girlfriends. T.S.'s former girlfriend, Brandi Svenning, is about to be auctioned off by her father in a dating game show being filmed at the mall. Brodie believes they can sabotage the game show

12 Bridget Kenny, "Retail, the Service Worker and the Polity: Attaching Labour and Consumption," Critical Arts 29, no. 2 (2015): 200.

13 The published script has a longer speech, suggesting that the Empire is a theocracy and the Emperor is a religious leader: "he's like the pope for the dark side of the Force. He's a holy man; a shaman, kind of, albeit an evil one." Dante says of the rebels, who fail to mention any religious beliefs, "I think they were Catholics."

14 Darren Jorgensen, "Death Star, or How I Learned to Stop Worrying and Love Globalization," symploke 15, nos. 1-2 (2007): 211. 
and he enlists Jay and Silent Bob's help. Jay claims, "We were gonna do that anyway. [...] Silent Bob stole the schematic of the stage from some foolish carpenter and found a weakness, just like the fucking Death Star." Brodie's own ex-girlfriend has meanwhile started dating Shannon Hamilton, a clerk at the Fashionable Male store who specializes in seducing women on the rebound.

The mall actively encourages processes of consumption, directing "the stroller to their windows and their wants; they become new social spaces, facilitating intimacies. ${ }^{15}$ The individual is thereby automatically transformed into a buyer within the flow of capital. Hamilton has no tolerance for those who refuse to consume - the mallrats. They engage in what Mike Presdee calls "proletarian shopping, ${ }^{116}$ a term he uses to describe the actions of unemployed youths who occupy mall spaces but do not make purchases. Indeed, John Fiske argues that such "youths consumed images and space instead of commodities, a kind of sensuous consumption that did not create profits. ${ }^{{ }^{17}}$ Despite Quint and Brodie's lack of a "shopping agenda," the heterosexual couplings of the narrative lead to Quint's wedding at the Universal Studios Jaws ride and Brodie presenting The Tonight Show, tying them both back to practices of media consumption.

Smith's third feature, Chasing Amy, includes a racial critique of the Star Wars trilogy by the first named African-American character to appear in the Asknewniverse films. At a comics convention, Hooper $\mathrm{X}^{18}$ parodies black nationalist and particularly Nation of Islam rhetoric, shouting: "Always some white boy gotta invoke the holy trilogy. Bust this: those movies are about how the white man keeps the brother down, even in a galaxy far, far away." Blond, blue-eyed, heroic Luke is an Aryan figure, whereas Darth Vader is "the blackest brother in the galaxy, Nubian god." Of course, this is partially true: Vader is voiced by James Earl Jones, the only black actor in A New Hope, but his body is that of the white English bodybuilder David Prowse and, in Return of the Jedi, Sebastian Shaw is substituted for the reveal of Vader's face. A New Hope's racial diversity is only supplied by alien species, offering "exotic beings [as] symbolically proxy for blacks and other people

\footnotetext{
15 Kenny, "Retail," 200.

16 Mike Presdee, Agony or Ecstasy: Broken Transitions and the New Social State of Working-Class Youth in Australia (Magill: South Australian Centre for Youth Studies, 1986), 16.

17 John Fiske, Reading the Popular (London: Routledge, 1989), 17.

18 The character may be inspired by Eric Griffin and Nabile P. Hage of the association ANIA, which brought together four black comic book publishers in 1993 to boost African-American readership and to compete with DC and Marvel's attempts at diversity.
} 
of color."19 Kevin J. Wetmore Jr. defends the film against Smith/X's charge of whites versus an evil black man by pointing out that the stormtroopers take their "name from the Nazis, and the members of the Imperial Command [have] uniforms based on the Nazis. ${ }^{20}$ Nevertheless, nearly all quasi-human characters remain white.

Hooper also objects to Lando Calrissian, labelling him an "Uncle Tom nigger." For Hooper and other critics, Calrissian is a token figure, rather than part of a wider social structure. Adilifu Nama notes that, in the context of post-Civil Rights, early Reaganite America, "Working and middle-class whites perceived that their economic well-being was threatened by the potential of black workers being hired or promoted past them because of affirmative action. ${ }^{21}$ Calrissian, despite or because he is a narrative agent substituted for Solo, is always already stigmatized by the racist attitudes of white audiences and therefore must be redeemed (and made ineffectual ${ }^{22}$ ) by the narrative.

Smith's critique of Lucas's shortcomings in representing diversity might be undermined by the revelation that Hooper's macho black militant attitudes are the performed persona of an effeminate gay man. Of course, Hooper's two personalities need not be mutually exclusive, but Hooper is a doubly token figure, standing in for all black and male homosexual identities in a film whose plot is about a straight man's romantic pursuit of a gay woman. ${ }^{23}$ Within the context of the film, however, Hooper's militant identity and publicity stunt is a sales pitch, adding economic value to his comic books. He appears to have appropriated Darth Vader as a symbol of black power inherent to the character's identity, but Chasing Amy is ambiguous as to how seriously we should take Hooper. Hooper's creative labor in his comic book, White Hatin' Coon, might be a personal expression of his identity, a cynical performance of one to make money, or a mixture of both.

19 Adilifu Nama, " $\mathrm{R}$ is for Race, Not Rocket: Black Representation in American Science Fiction Cinema," Quarterly Review of Film and Video 26, no. 2 (2009): 159.

20 Kevin Wetmore Jr., The Empire Triumphant: Race, Religion and Rebellion in the Star Wars Films (Jefferson, NC: McFarland, 2005), 128.

21 Nama, "R is for Race," 160.

22 Wetmore Jr., The Empire Triumphant, 133. Wetmore argues that he is ineffectual in the rescue of Han in Return of the Jedi and indeed needs to be rescued himself by the blind Han.

23 Smith returns to militant black male characters with Rufus in Dogma and Chaka LutherKing in Jay and Silent Bob Strike Back, both played by and drawing on the comic persona of Chris Rock. 
Smith's evident interest in comic books gave him both an ambition to write in the medium and the opportunity to do so once he was an established figure. After writing about Jay and Silent Bob and their superhero alter egos Bluntman and Chronic in issues of Oni Double Feature, Smith wrote the one-shot Clerks. (The Comic Book). The Clerks. comic dramatizes the economics of Star Wars collectibles, focusing on characters who buy increasingly specific toys: Handless Luke, Cremated Anakin Skywalker, Shriekin' Luke Skywalker, and so on. Randal spies an opportunity to make money by buying the in-demand toys to resell at a premium. Dante is surprised that the manufacturer has not increased production to satisfy demand, which Randal dismisses as "commie talk," as that would undermine the freedom of the secondary market. Merchandising is explicitly compared to "the billion dollar drug and sex markets"; all three appear to be satisfying needs that the market does not fully gratify. The supplier controls when the purchase can be made — with only limited numbers made available — just as a dealer controls the selling of drugs.

In the comic, Randal and Dante go in search of a supplier, Lord Howell, who provides them with examples of Wave Sixty-Nine toys (with obvious sexual connotations). Their foray into the free market is stopped by Jay and Silent Bob, who recognize that only a limited amount of disposable income is spent on merchandising rather than weed and pills. Understanding the power of supply and demand, Jay and Silent Bob hijack a truck carrying Wave Seventy merchandising and flood the market with loss-leading toys, driving other dealers out of business. Jay and Silent Bob then return to dealing. This exaggerated comparison between merchandising and drugs may suggest a negative view of collecting. But on the other hand, Askewniverse films take a neutral-to-positive view of drugs: in this world, there are no overdoses or addicts. The characters in the comic may be cynical about Star Wars's attempts to build surplus value through new versions and formats, but the comic is itself an example of merchandising designed to attract viewers of the films and to deliver an audience to those movies. In an early interview with film producer John Pierson before the release of Mallrats, Smith said, "What am I gonna do? Put Silent Bob on a shirt?"24 Within a few years, however, Smith did indeed have his own line of merchandising, clothing, toys, posters, and more. His Askewniverse materials precisely mimic Lucasfilm's attempts to brand its audience-to make a permanent mark of identity upon them and to deliver a lucrative cohort of laborer-watchers.

24 John Pierson, Spike, Mike, Slackers and Dykes: A Guided Tour Across a Decade of American Independent Cinema (New York: Hyperion, 1997), 201. 
Perhaps Smith's biggest attempt to deliver laborer-watchers came when, with Dave Mandel, he developed Clerks: The Animated Series. However, ABC got cold feet about ratings, canceling it after just two episodes. An animated George Lucas appears in the second broadcast episode, "A Dissertation on the American Justice System by People Who Have Never Been Inside a Courtroom, Let Alone Know Anything About the Law, But Have Seen Way Too Many Legal Thrillers" (2000). Randal sues Dante on Jay's behalf and inexplicably calls Lucas as a witness, asking him "do you think Phantom Menace is as good a movie as Empire?" Having pointed out two contradictions between the original trilogy and the new film, Randal alleges that Lucas "knew this was a bad movie, that you wrote it over a weekend but kept telling people it was done for years." Randal here represents adult disappointment at the new material not matching up to the films they had loved as children and teenagers. He challenges Lucas in a way that many fans, such as those represented by the documentary The People vs. George Lucas (2010), would be happy to second.

Blaming "Uncle" George, the once-reassuring father-figure, acknowledges the hierarchy of textual authority from the original holy trilogy down to fan writing, from author as owner through author-for-hire to amateur authorship that is a form of unpaid labor. Will Brooker argues that "George Lucas's involvement is absolutely paramount for a text to be considered genuinely canonical. ${ }^{25}$ Therefore, it is Lucas's responsibility if canon disappoints, even if he did not create it. Respect for his authorial status began to unravel following criticism of changes he made to re-releases and special editions of the original trilogy in the late 1990s and early 2000s, as well as the many disappointments of the prequel trilogy. One change considered particularly egregious by fans was the re-editing of the Mos Eisley cantina scene in $A$ New Hope, in which Han shoots and kills the bounty hunter Greedo. In the 1997 special edition, Greedo shoots first, undermining the earlier sense of Han's moral ambiguity. ${ }^{26}$ Meanwhile, whilst Lucasfilm is happy about the activities of laborer-watchers in their consumption of merchandising and is dependent upon their advertising, the move to production in terms of fan fiction and subcreation is commonly regarded with a degree of suspicion. ${ }^{27}$

25 Will Brooker, "Internet Fandom and the Continuing Narratives of Star Wars, Blade Runner and Alien," in Alien Zone II: The Spaces of Science-Fiction Cinema, ed. Annette Kuhn (London: Verso, 1999), 67.

26 In the 2004 DVD, they shoot in unison.

27 Whilst various products and films have been thought to infringe Lucasfilm's Intellectual Property, the production company co-ran The Official Star Wars Fan Film Awards 2002-11 and 2015-2016. 
This policing of intellectual property (IP) is at the heart of Jay and Silent Bob Strike Back, as Hollywood attempts to make a film featuring Jay and Silent Bob's alter egos, Bluntman and Chronic. Chasing Amy had established that McNeill and Edwards pay likeness rights money to the two drug dealers; they wish to protect their identities and wish to control their exploitation. In the course of the film, Smith references a variety of other films and television programs - The Matrix, The Fugitive, and the Scooby-Doo and Star Wars franchises. Jay and Silent Bob seem unlikely metonyms for the Empire, but the pre-film caption- "A long time ago, at a convenience store not so far away" - is a variant on Star Wars's iconic opening frame. Moreover, the logo of the film copies the stylized rendition of the Star Wars titles.

The film also includes a cameo from Carrie Fisher, who plays a nun. As Leia, Fisher offered a first crush for many of Smith's age and older, as she was initially presented as a self-reliant and resourceful protagonist who later turns out to be Luke's twin. While Fisher rewrote later scripts, the character lost agency through the series. Post-Star Wars, much of her work was in cameos, while she worked as a script doctor and bestselling writer. Playing a nun, she exhibits a fetishizable chastity, with Jay's rejected cunnilingus taboo. Mark Hamill is cast (as himself) playing the role of Cockknocker, the villain of the comic and film Bluntman and Chronic. An onscreen caption “HEY KIDS! IT'S MARK HAMILL! [APPLAUSE!]” prods us to recognize him, in one of several fourth-wall-breaking moments in the film. There follows a parody of lightsaber fights, albeit with bongs, and Jedi-style acrobatics, with Jay calling himself Darth Balls and wielding a double-piped bong in reference to Darth Maul in The Phantom Menace. Hamill, soi-disant Jedi master, loses a hand with the exasperated aside to camera, "Not again."

The director of the film-within-the film, Chaka Luther-King, suggests that Lucas might sue. Lucasfilm is happy with laborer-watchers to the extent that such work delivers capital to them or to create a personal identity, but it does not wish them to make capital of their own from poached IP. There is a narrow line being trod. Randal had sought to profit from the Force but was unable to because of Jay and Silent Bob, who now stand to make money from their own IP as well as their drugs.

These likeness rights provide a kind of deus ex machina for Dante and Randal in the final Askewniverse film to date. Clerks II opens with them in their old jobs - although they lose them right away as Randal burns the premises down. They move from being wage slaves for a family business to slinging hash for a major fast-food franchise. But Dante has an escape plan: he can move to Florida with his girlfriend Emma, where her father will give him a house and a car wash to run. This is perhaps a step up from 
working for someone else, but Dante has benefited from nepotism rather than succeeding on the merits of hard work.

The sharing of cultural capital continues to distract them from their exploitation, even if the sources are in flux. At the time, Peter Jackson's The Lord of the Rings trilogy seemed to be eclipsing Star Wars as a pop-cultural phenomenon. Randal might insist, "there's only one 'Return,' okay, and it ain't of the King,' it's 'of the Jedi,"' but a generation of viewers born after Return of the Jedi needed more convincing. The dismissal of Jar Jar Binks and the performances of the actors playing Anakin ("Manikin Skywalker") by Randal's coworkers and customers strike a nerve. Former high school acquaintance Lance Dowds, now an internet millionaire, sneeringly suggests that they are still arguing over whether Han or Greedo shot first.

The engaged Dante continues to postpone marriage to Emma-having been in a relationship with Veronica at the end of Clerks - by getting his branch manager Becky pregnant. His dream is to marry Becky and maintain his three-decades-plus friendship with Randal by returning to work at the Quick Stop. This requires capital, which Jay and Silent Bob lend him, thanks to the aforementioned likeness rights monies. Dante returns to where he started, but now working for himself, and will most likely end up exploiting others. Thus, the overall story arc of the Askewniverse takes a Generation $\mathrm{X}$ slacker from a McJob to being a business owner and father. At the same time, Smith constantly drew upon Star Wars as part of his intertextual referencing. While he could appear critical of "Uncle George" or "George Toyboy Lucas" as he moved from consumer to prosumer to producer, parody still allowed parasitism of others' IP, especially Lucas's, in the production of his own transmedia storyworld.

Wood argues that, in the original Star Wars trilogy,

The Father must here be understood in all senses, symbolic, literal, potential [...] [including] the young heterosexual male, father of the future, whose eventual union with the "good woman" has always formed the archetypal happy ending of the American film, guarantee of the perpetuation of the nuclear family and social stability. ${ }^{20}$

After a dozen years, Dante becomes that young heterosexual male, while Becky becomes that good woman; in Clerks II, Dante finally becomes the patriarchal capitalist. 
It may be that Star Wars's cultural capital distracts from the wider economic picture. Dante even admits:

I'd hardly call Star Wars the biggest thing to happen to our generation. It's a movie that-granted - the flannel-wearing set of our generation seem to obsess over ... present company especially ... but it's still just a movie. Trust me, after the over-exposure of the re-release, no one but you gives a rat's ass about your precious trilogy anymore. ${ }^{29}$

And yet, the box office success of the prequels and the Disney-era The Force Awakens and Rogue One might contradict this. The branding continues and Smith clearly remains a Lucas fan. In his shifts between self-financing, studio funding, and work-for-hire, Smith's auteurist signature, his own IP, is evidently made in part through his own laborer-watching of Lucas's franchise. 